\title{
Morin inhibits PDGF-induced proliferation, migration, and invasion of vascular smooth muscle cells via modulating p27KIP1, AKT, and MMP-9 activities
}

\author{
Seung-Shick Shin ${ }^{1^{*}}$, Myeong-Cheol Ko ${ }^{2^{*}}$, Dae-Hwa Noh ${ }^{3}$, Byungdoo Hwang ${ }^{3}$, Yujin Park ${ }^{3}$, \\ Sung Lyea Park ${ }^{3}$, Wun-Jae Kim ${ }^{4}$ and Sung-Kwon Moon ${ }^{3}$ \\ ${ }^{1}$ Department of Food Science and Nutrition, Jeju National University, Jeju 63243, South Korea \\ ${ }^{2}$ Department of ICT Convergence Engineering, College of Science and Technology, Konkuk University, Chungju, Chungbuk \\ 27478, South Korea \\ ${ }^{3}$ Department of Food and Nutrition, Chung-Ang University, Anseong 17546, South Korea \\ ${ }^{4}$ Department of Urology, Chungbuk National University, Cheongju 28644, South Korea
}

\begin{abstract}
Hyper-proliferation and migration of vascular smooth muscle cells (VSMCs) are closely associated with atherosclerosis. Recently, the flavonol morin has been reported to exhibit potent anti-oxidant and anti-inflammatory activities. Therefore, we investigated molecular mechanisms of morin in VSMCs stimulated by PDGF. Morin effectively inhibited PDGF-stimulated proliferation of VSMCs through a G1 cell-cycle arrest, leading to down-regulation of CDK2, CDK4, cyclin D1, and cyclin E proteins. Interestingly, PDGF markedly down-regulated p27KIP1 protein expression; however, morin treatment restored the p27KIP1expression to the basal level. Morin did not affect phosphorylation of MAPKs (ERK, p38, and JNK); however, phosphorylation of AKT was dramatically suppressed by morin in PDGF-stimulated VSMCs. Using the PI3K inhibitor, LY294002, we revealed that AKT is a key regulator in the inhibitory mechanism of morin against PDGF-induced proliferation of VSMCs. Morin disturbed migratory and invasive potential of VSMCs via suppression of matrix metalloproteinase-9 (MMP-9) activity. Using electrophoretic mobility shift assays, we verified that NF- $\mathrm{KB}, \mathrm{AP}-1$, and Sp-1 transcription factors are implicated in the mode of action of morin, which suppresses the MMP-9 activity in PDGF-induced VSMCs. Based on the results, we believe that morin may be a potential therapeutic agent for atherosclerosis without negative side effect.
\end{abstract}

Key words: Morin - VSMC - Proliferation - Migration - Invasion

\begin{abstract}
Abbreviations: AP-1, activator protein-1; CDK, cyclin-dependent protein kinase; ERK, extracellular signal-regulated kinase; JNK, c-Jun N-terminal kinase; MAPK, mitogen-activated protein kinase; MMP, matrix metalloproteinase; NF- $\kappa B$, nuclear factor- $\kappa B$; PDGF, platelet-derived growth factor; PI3K, phosphoinositide 3-kinase; Sp-1, specificity protein-1; VSMC, vascular smooth muscle cells.
\end{abstract}

\section{Introduction}

Atherosclerosis is a chronic disease of blood vessels characterized by accumulation of lipids, infiltration of immune

Correspondence to: Sung-Kwon Moon, Department of Food and Nutrition, Chung-Ang University, 4726 Seodong-Daero, DaedeokMyeon, Anseong, 17546, South Korea

E-mail: sumoon66@cau.ac.kr

${ }^{\star}$ These authors contributed equally to this work. cells, and proliferation of vascular smooth muscle cells (VSMCs) within the intimal layer of the artery (Ross 1993; Turunen et al. 1999). VSMCs are mainly associated with cellular repair processes from tissue injury; however, in chronic inflammatory conditions, these cells facilitate intimal thickening, which may cause the onset of cardiovascular diseases, such as atherosclerosis, stroke, ischemia, and infarction (Singh et al. 2002; Chistiakov et al. 2015).

VSMCs proliferate and migrate into the intimal layer following vascular injury in atherosclerotic lesions (Singh et 
al. 2002). Growth factors and cytokines produced by several types of cells, including macrophages, endothelial cells, and VSMCs, contribute to the development and progression of vascular lesions (Doran et al. 2008). Platelet-derived growth factor (PDGF), a significant regulator of mitogenesis, influences the proliferation of VSMCs through the activation of c-Jun N-terminal kinase (JNK), extracellular signalregulated kinase (ERK) 1/2, p38 mitogen-activated protein kinase (MAPK), and AKT signaling pathways (Heldin and Westermark 1999). In response to extracellular stimuli, cells progress through cellular division in four distinct sequential phases, G0/G1, S, G2, and M, which are controlled by cell cycle regulators, such as cyclins, cyclin-dependent protein kinases (CDKs), and CDK inhibitors, including p21WAF1 and p27KIP1 (Zetterberg et al. 1995; Lee and Yang 2001; Li and Blow 2001).

In atherosclerotic lesions, collagen degradation and extracellular matrix reorganization are increased, and eventually medial VSMCs migrate into the intimal space of the vessel wall, which is primarily mediated by matrix metalloproteinases (MMPs) (Newby and Zaltsman 2000; Galis and Khatri 2002b). The MMPs are a family of extracellular matrix-degrading proteases that have been implicated as crucial regulators of atherosclerosis development (Chase and Newby 2003). These proteases have been reported to be expressed in inflammatory lesions of artery plaques, suggesting a crucial role in the pathogenesis of atherosclerosis (Caird et al. 2006). Animal studies performed by others have shown that elevated levels of MMPs, such as MMP-2 and MMP-9, are key risk factors in the progression of atherosclerosis (Guo et al. 2009; Wagsater et al. 2011). Particularly, MMP9 has been reported as a regulator of the proliferation and migration of VSMCs (Cho and Reidy 2002). The proteolytic activity of MMP-9 is enhanced by extracellular stimuli, such as insulin-like growth factor-1 (IGF-1) and platelet-derived growth factor-BB (PDGF-BB), through MAPKs and phosphoinositide 3-kinase (PI3K)/AKT signaling pathways (Cho et al. 2000; Lee et al. 2007; Zhuang et al. 2013). In addition, analysis of MMP-9 promoter activity has suggested that it contains essential activator protein-1 (AP-1), specificity protein $1(\mathrm{Sp}-1)$, and nuclear factor $(\mathrm{NF})-\kappa \mathrm{B}$ binding sites.

Morin (3, 20, 40, 5, 7-pentahydroxyflavone) is a yellowpigmented flavonol isolated from the plant family of Moraceae. Recent studies have demonstrated that it exhibits a broad spectrum of biological activities, including antioxidant, anti-inflammatory, free-radical scavenging, and anti-carcinogenic properties (Sivaramakrishnan et al. 2009; Jin et al. 2014). Although the biological effects of morin on the proliferation of various cells have been reported (Kanno et al. 2005; Jin et al. 2014; Chung et al. 2016), the molecular mechanisms underlying its anti-atherogenic effects have not been clearly identified. In this study, we investigated the anti-migratory and anti-proliferative effects of morin and demonstrate the cellular mechanisms of morin-mediated inhibition of cell cycle progression, regulation of early gene expression, and suppression of MMP-9 activity in PDGFinduced VSMCs.

\section{Materials and Methods}

\section{Materials}

Morin was purchased from Sigma-Aldrich (St. Louis, MO, USA). Polyclonal antibodies of ERK, phospho-ERK, p38MAPK, phospho-p38MAPK, JNK, phospho-JNK, AKT, and phospho-AKT were obtained from Cell Signaling Technology (Danvers, MA, USA). Polyclonal antibodies against cyclin D1, cyclin E, CDK2, CDK4, p21WAF1, p27KIP1, p53, and glyceraldehyde 3-phosphate dehydrogenase (GAPDH) were obtained from Santa Cruz Biotechnology (Santa Cruz, CA, USA). Anti-MMP-9 polyclonal antibody was purchased from Chemicon (Temecula, CA, USA).

\section{Cell culture}

VSMCs were isolated from Sprague-Dawley rats and grown in $1 \times$ DMEM containing $10 \%$ fetal bovine serum (FBS), $2 \mathrm{mM}$ glutamine, $50 \mathrm{mg} / \mathrm{ml}$ gentamycin, and $50 \mathrm{ml} / \mathrm{ml}$ amphotericin-B at $37^{\circ} \mathrm{C}$ in a humidified $\mathrm{CO}_{2}(5 \%)$ incubator.

\section{Cell viability assay}

Cell viability was measured by both the 3-(4,5-dimethylthiazol-2-yl)-2,5-diphenyltetrazolium bromide (MTT) and viable cell counting assays. For the MTT assays, $6 \times 10^{3}$ cells were plated per well in 96-well plates and preincubated with morin for $1 \mathrm{~h}$ at concentrations of $0,50,100$, or $200 \mu \mathrm{M}$, followed by incubation with PDGF $(20 \mathrm{ng} / \mathrm{ml})$ for $24 \mathrm{~h}$. After incubation, the medium was aspirated and fresh medium containing $10 \mu \mathrm{l}$ of $5 \mathrm{mg} / \mathrm{ml}$ MTT was added. After $1 \mathrm{~h}$, the medium was aspirated and $100 \mu \mathrm{l}$ dimethyl sulfoxide (DMSO) was added. The absorbance at $540 \mathrm{~nm}$ was measured using a fluorescence plate reader. For viable cell counting, $50 \mu \mathrm{l}$ of detached cells were mixed with $50 \mu$ of $0.4 \%$ trypan blue (Sigma-Aldrich) by gentle pipetting, and the blue-stained dead cells were counted using a hemocytometer. Viable cells were calculated using the equation: $\%$ viable cells $=[1.00-$ (number of blue cells $\div$ number of total cells) $] \times 100$.

\section{Cell cycle analysis}

VSMCs were preincubated with morin at concentrations of $0,50,100$, or $200 \mu \mathrm{M}$ for $1 \mathrm{~h}$, and then cells were incubated in the absence or the presence of PDGF $(20 \mathrm{ng} / \mathrm{ml})$ for $24 \mathrm{~h}$. The cells were collected and washed twice with phosphate- 
buffered saline (PBS). After centrifugation at 1,000 $\times g, 5 \mathrm{ml}$ of ice-cold ethanol $(70 \%(v / v))$ was added dropwise; the cell pellets were resuspended, and stored at $4^{\circ} \mathrm{C}$ overnight. The cells were collected again by centrifugation and resuspended in $1 \mathrm{ml}$ of PBS containing RNase $\mathrm{A}(100 \mu \mathrm{g} / \mathrm{ml})$ and propidium iodide (PI, $100 \mu \mathrm{g} / \mathrm{mL}$ ), followed by incubation at $37^{\circ} \mathrm{C}$ for $30 \mathrm{~min}$. Cell-cycle distribution was analyzed by a flow cytometer (FACStar ${ }^{\mathrm{m}}$, Becton Dickinson, Franklin Lakes, NJ, USA) supplied with BD Cell FIT software.

\section{Immunoblot}

Cells were washed twice with cold PBS and freeze-thawed in $200 \mu \mathrm{l}$ lysis buffer containing $50 \mathrm{mM}$ HEPES ( $\mathrm{pH} 7.5$ ), $150 \mathrm{mM} \mathrm{NaCl}, 1 \mathrm{mM}$ EDTA, $1 \mathrm{mM}$ dithiothreitol (DTT), $2.5 \mathrm{mM}$ EGTA, $10 \mathrm{mM} \beta$-glycerophosphate, $0.1 \mathrm{mM} \mathrm{Na}$ ${ }_{3} \mathrm{VO}_{4}, 1 \mathrm{mM} \mathrm{NaF}, 0.1 \mathrm{mM}$ phenylmethylsulfonyl fluoride (PMSF), 10\% glycerol, 0.1\% Tween-20, $10 \mu \mathrm{g} / \mathrm{ml}$ leupeptin, and $2 \mu \mathrm{g} / \mathrm{ml}$ aprotinin. After cells were scraped into $1.5 \mathrm{ml}$ tubes, the lysates were incubated on ice for $10 \mathrm{~min}$. Then, the cells were centrifuged at $10,000 \times g$ for $10 \mathrm{~min}$ at $4^{\circ} \mathrm{C}$. The amount of protein was determined by a BCA protein assay reagent kit (Thermo Fisher Scientific Inc., Waltham, MA, USA). Twenty-five micrograms of each protein was loaded and separated by electrophoresis on a $0.1 \%$ SDS, $10 \%$ polyacrylamide gel (SDS-PAGE) under denaturing conditions. The proteins were transferred electrophoretically to nitrocellulose membranes (Hybond, GE Healthcare Bio-Sciences, Marlborough, MA, USA). After blocking with 5\% skim milk, the membranes were incubated with primary antibodies for $12 \mathrm{~h}$, washed, incubated with peroxidase-conjugated secondary antibodies for $90 \mathrm{~min}$, and washed again. The immunocomplexes were detected by chemiluminescence reagent kit (GE Healthcare Bio-Sciences, Marlborough, MA, USA). Experiments were repeated at least 3 times.

\section{Immunoprecipitation}

For the immunoprecipitation assay, equal amounts of cell lysates were incubated with specific antibodies overnight at $4^{\circ} \mathrm{C}$. Immunocomplexes were rendered insoluble using protein A-sepharose beads (Santa Cruz Biotechnology, Inc.), followed by incubation at $4^{\circ} \mathrm{C}$ for $2 \mathrm{~h}$. The immunoprecipitates were washed with lysis buffer 3 times, and then resuspended in SDS-PAGE sample buffer containing $\beta$-mercaptoethanol (Bio-Rad, Richmond, CA, USA). The samples were analyzed by immunoblot analysis, as indicated in the previous section.

\section{Wound healing assay}

VSMCs were seeded into 6-well plates and grown to $90 \%$ confluence. Then, cells were pretreated with mitomycin C ( $5 \mu \mathrm{g} / \mathrm{ml}$, Sigma-Aldrich, \#M4287) for $2 \mathrm{~h}$ to inhibit cell proliferation. The surface of the cells was scratched with a $200 \mu \mathrm{l}$-pipette tip, and the well was washed with PBS to remove floating cells. Cells were treated with morin $(0,50$, 100 , or $200 \mu \mathrm{M}$ ) for $1 \mathrm{~h}$, followed by incubation of the cells in the presence or absence of PDGF $(20 \mathrm{ng} / \mathrm{ml})$ for $24 \mathrm{~h}$. The migration of cells was photographed using an inverted microscope (40× magnification).

\section{Invasion assay}

PDGF-induced VSMCs $\left(2.5^{\prime} 10^{4}\right)$ were resuspended in $100 \mu \mathrm{l}$ of medium containing morin $(0,50,100$, or $200 \mu \mathrm{M})$ and placed in the upper chamber of a transwell migration plate. After $24 \mathrm{~h}$, the cells that invaded the matrix (a polycarbonate membrane with $8-\mu \mathrm{m}$ pores and a thin layer of the ECM-like material, Matrigel) were fixed, stained, photographed, and analyzed using a commercial cell invasion assay kit (Chemicon International, Billerica, MA) and ImageJ software (National Institutes of Health, USA). The number of invading cells was measured as fold changes compared to the control.

\section{Zymography}

Conditioned medium was collected and electrophoresed on a polyacrylamide gel containing $0.25 \%$ gelatin. The gel was washed twice for $15 \mathrm{~min}$ at room temperature with $2.5 \%$ Triton X-100. Subsequently, the gel was incubated at $37^{\circ} \mathrm{C}$ overnight in a buffer containing $150 \mathrm{mM} \mathrm{NaCl}, 50 \mathrm{mM}$ Tris$\mathrm{HCl}$, and $10 \mathrm{mM} \mathrm{CaCl}_{2}, \mathrm{pH}$ 7.5. The gel was stained with $0.2 \%$ Coomassie blue and photographed on a light box. Proteolysis was detected as a white zone on a blue background.

\section{$R N A$ extraction and real-time PCR}

Total RNAs were extracted using an RNeasy mini kit (Qiagen, La Jolla, CA, USA). Complementary DNA was prepared using RT-PCR master mix with random hexamers according to the manufacturer's instructions (GE health care biosciences, Pittsburgh, PA, USA). PCR was performed in a Mastercycler (Eppendorf, Hamburg, Germany) with the indicated primers. The real-time PCR cycling conditions were $95^{\circ} \mathrm{C}$ for $5 \mathrm{~min}, 40$ cycles for $30 \mathrm{~s}$ at $95^{\circ} \mathrm{C}, 20 \mathrm{~s}$ at $55^{\circ} \mathrm{C}$ and $30 \mathrm{~s}$ at $72^{\circ} \mathrm{C}$, followed by fluorescence measurement. The primer sequences used were as follows: MMP-9 sense ( $5^{\prime}$-ttccctggagacctgagaacc- $\left.3^{\prime}\right)$ and MMP-9 antisense ( $5^{\prime}$-cggcaagtcttccgagtagtttt $\left.3^{\prime}\right)$.

\section{Nuclear extracts and electrophoretic mobility shift assay (EMSA)}

The cells were incubated with fresh serum-free media containing the indicated concentration of morin $(0,50$, 
100 , or $200 \mu \mathrm{M})$. After $24 \mathrm{~h}$, the media was replaced with serum-free media containing the $20 \mathrm{ng} / \mathrm{ml}$ PDGF for $24 \mathrm{~h}$. The nuclear extracts were prepared as follows. The cells were incubated in lysis buffer (0.5 mM PMSF, $0.1 \mathrm{mM}$ EGTA, $0.1 \mathrm{mM}$ EDTA, $1 \mathrm{mM}$ DTT, $10 \mathrm{mM} \mathrm{KCl}, 10 \mathrm{mM}$ HEPES, $\mathrm{pH}$ 7.9) on ice for $15 \mathrm{~min}$, and then were scraped and collected in a new tube. The cells were vortexed gently in $0.5 \%$ Nonidet P-40, and then centrifuged at 12,000 rpm for $1 \mathrm{~min}$. The nuclear pellet was re-suspended in a buffer ( $1 \mathrm{mM}$ EGTA, $1 \mathrm{mM}$ DTT, $1 \mathrm{mM}$ PMSF, $0.4 \mathrm{M} \mathrm{NaCl}, 1 \mathrm{mM}$ EDTA, and $20 \mathrm{mM}$ HEPES, pH 7.9) for $20 \mathrm{~min}$ at $4^{\circ} \mathrm{C}$. After the addition of $\mathrm{KCl}$ (final concentration of $500 \mathrm{mM}$ ) and incubation for $1 \mathrm{~h}$ at $4^{\circ} \mathrm{C}$, the samples were centrifuged for $1 \mathrm{~min}$ at $12,000 \mathrm{rpm}$. Protein in nuclear extracts was determined using the Bradford reagent method (Bio-Rad). The probes of consensus oligonucleotide sequences for AP- $1, N F-\kappa B$, and $\mathrm{Sp}-1$ were based on the cis element in the MMP-9 promoter, as follows: AP-1 (CGCTTGATGAGTCAGCCGGAA), NF- $\kappa$ B (AGTTGAGGGGACTTTCCCAGGC), and Sp-1

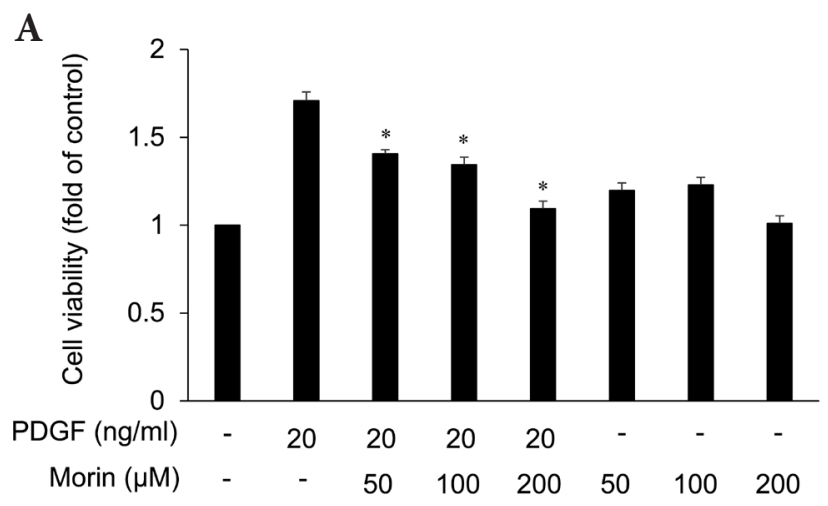

B

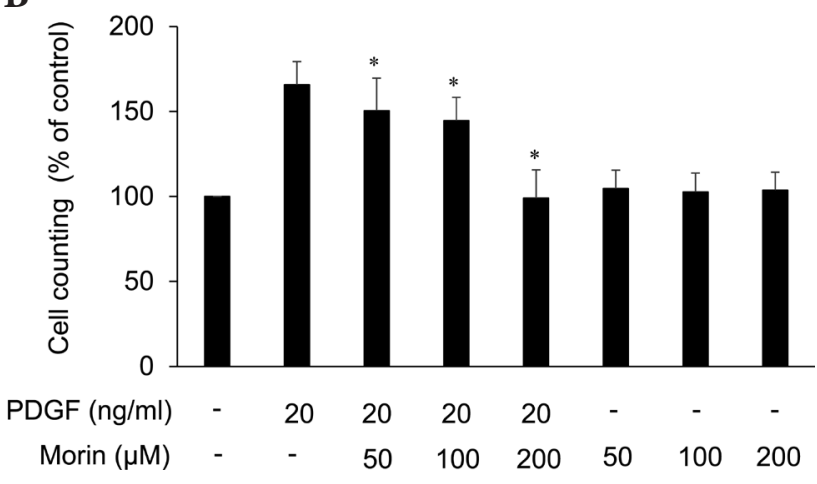

Figure 1. Inhibition of cell viability and proliferation of PDGFinduced VSMCs by morin. A. Cell viability was assessed by MTT assays. VSMCs were serum-starved for $24 \mathrm{~h}$, followed by preincubation with 50,100 , or $200 \mu \mathrm{M}$ of morin for $1 \mathrm{~h}$. Then, PDGF $(20 \mathrm{ng} / \mathrm{ml})$ was added and incubated for $24 \mathrm{~h}$. B. Viable cells were counted by the trypan blue staining exclusion method. Results are presented as the means \pm SD from three experiments; ${ }^{\star} p<0.05$ versus treatment with PDGF alone.
(ATTCGATCGGGGCGGGGCGAGC). An EMSA assay was performed by annealing the complementary oligonucleotides in an annealing buffer $(50 \mathrm{mM} \mathrm{NaCl}, 10 \mathrm{mM}$ Tris $\mathrm{pH} 8,1 \mathrm{mM}$ EDTA) with heating at $90^{\circ} \mathrm{C}$ for $2 \mathrm{~min}$. AP-1, NF- $\kappa$ B, and Sp-1 oligonucleotides were end-labeled by incubation of $\mathrm{T} 4$ polynucleotide kinase (Promega) and $\left[\gamma^{-32} \mathrm{P}\right] \mathrm{ATP}$ at $37^{\circ} \mathrm{C}$ for $1 \mathrm{~h}$. The nuclear extract $(10-20 \mu \mathrm{g})$ was incubated in $2 \times$ binding buffer $(25 \mathrm{mM}$ HEPES $(\mathrm{pH}$ 7.6), $1 \mathrm{mM}$ EDTA, $0.5 \mathrm{mM}$ DTT, $5 \mathrm{mM} \mathrm{MgCl}_{2}$, $75 \mathrm{mM}$ $\mathrm{KCl}, 10 \%$ glycerol) for $30 \mathrm{~min}$ at room temperature with the ${ }^{32} \mathrm{P}$-labeled oligonucleotide probe. The DNA-protein complexes were electrophoresed on a native $6 \%$ polyacrylamide gel using $0.5 \times \mathrm{TBE}$ running buffer. The gel was then washed, dried, and visualized with auto-radiography using X-ray film at $-70^{\circ} \mathrm{C}$ overnight (Moon et al. 2004). Unlabeled AP-1, Sp-1, and NF- $\kappa$ B oligonucleotides were used for competitive binding samples.

\section{Statistical analysis}

Where appropriate, data are represented as the means \pm SD. Data were evaluated by factorial ANOVA and a Fisher's least significant difference test where appropriate. Statistical significance was considered at $p<0.05$.

\section{Results}

\section{Morin inhibits PDGF-induced proliferation of VSMCs in a concentration-dependent manner}

It has been reported that PDGF is a strong mitogenic stimulant for the proliferation of VSMCs (Azahri et al. 2012). In order to examine the effect of morin on the proliferation of VSMCs, we pre-treated VSMCs in the absence or presence of morin at different concentrations $(50,100$, or $200 \mu \mathrm{M})$ for $1 \mathrm{~h}$, followed by incubation with PDGF $(20 \mathrm{ng} / \mathrm{ml})$ for $24 \mathrm{~h}$. The MTT assay showed that treatment with PDGF increased proliferation of VSMCs 1.7-fold, compared to that of the untreated control. However, PDGF-induced VSMCs exhibited a concentration-dependent reduction in their proliferation in the presence of morin. The proliferation of VSMCs, treated with morin alone, was not significantly different compared to that of the control (Figure 1A). In addition, the results from the viable cell counting assay exhibited a similar pattern to that of the MTT assay (Figure 1B).

\section{Morin induces G1-phase cell cycle arrest in PDGF-treated VSMCs}

Next, we examined whether morin induces growth inhibition of VSMCs through cell-cycle arrest. The cells were pretreated with different concentrations of morin for $1 \mathrm{~h}$, 
followed by incubation in the presence or absence of PDGF $(20 \mathrm{ng} / \mathrm{ml})$ for $24 \mathrm{~h}$. The cells were then subjected to flow cytometric analysis. As displayed in the fluorescenceactivated cell sorting (FACS) histograms of Figure 2A-F, morin-treated VSMCs accumulated in the G1 cell cycle phase in a concentration-dependent manner. Notably, the cell population in G1 increased from $55.5 \%$ in the cells treated with PDGF only to $67.6 \%$ in the cells treated with $200 \mu \mathrm{M}$ morin, with simultaneous decreases in both the $\mathrm{S}$ - and G2/M-phase populations as the morin concentration increased (Figure $2 \mathrm{~A}-\mathrm{F}$ ). These results demonstrate that morin induces G1-phase arrest of VSMCs, leading to inhibition of cell proliferation.

Morin induces G1-phase cell cycle arrest via suppression of positive cell cycle regulators by up-regulation of p27KIP1 in PDGF-treated VSMCs

It has been well demonstrated that cyclins, CDKs, and $\mathrm{CDK}$ inhibitors participate in the regulation of cell cycle progression in response to extracellular stimuli (Massague 2004). We investigated the effect of morin on expression of regulatory proteins associated with the $\mathrm{G} 1$-cell cycle phase. Stimulation with PDGF $(20 \mathrm{ng} / \mathrm{ml})$ led to up-regulation of
CDK2, CDK4, cyclin D1, and cyclin E. However, protein levels of these regulators were diminished by pretreatment with morin (Figure 3A). Subsequently, we examined expression of CDK inhibitors (p21WAF1 and p27KIP1) and the tumor suppressor, p53, to understand the mechanism of morin-mediated cell cycle arrest at G1-phase. As shown in Figure 3B, the expression of p21WAF1 was up-regulated by PDGF treatment, which was not influenced by morin treatment. Interestingly, protein expression of p27KIP1 was down-regulated by PDGF treatment; however, pretreatment with morin followed by PDGF-stimulation up-regulated p27KIP1. No correlation was observed between p53 levels and morin treatment (Figure $3 \mathrm{~B}$ ). We next performed immunoprecipitation (IP) analysis to verify that p27KIP1 plays a key role in the regulatory mechanism of morin. We utilized anti-CDK2 and anti-CDK4 antibodies to immunoprecipitate the binding partners, followed by immunoblotting with anti-p27KIP1 antibody. As shown in Figure $3 \mathrm{C}$, the decreased $\mathrm{p} 27 \mathrm{KIP} 1$ bound to CDK2 and CDK4 in PDGF-treated VSMCs was increased by morin treatment. These results clearly demonstrate that morin-mediated growth inhibition is associated with down-regulation of CDK2, CDK4, cyclin D1, and cyclin E and up-regulation of p27KIP1 in PDGF-treated VSMCs.
A

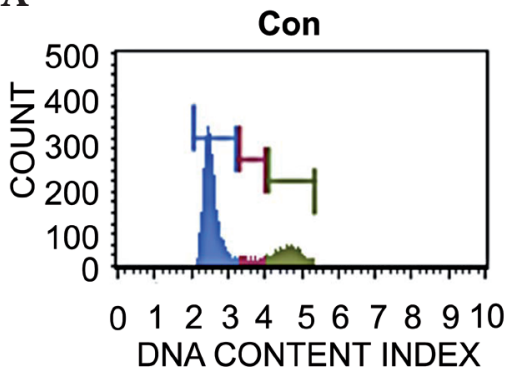

D

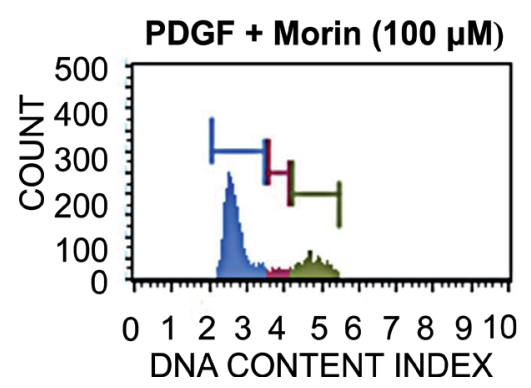

B

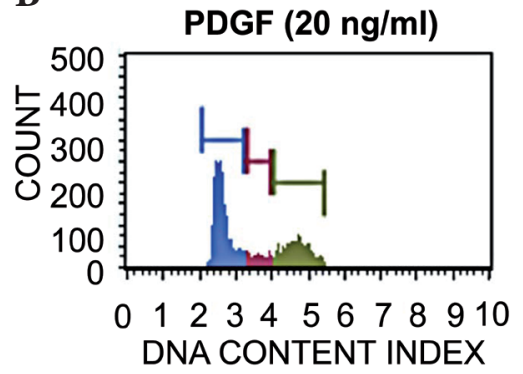

E

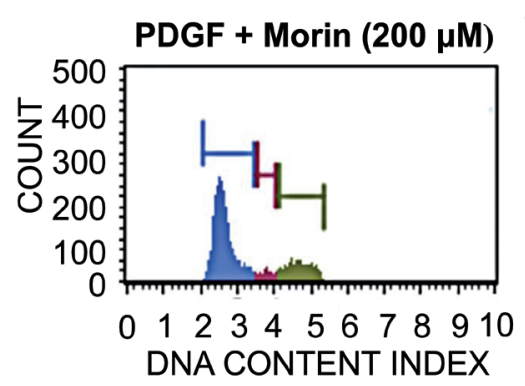

C

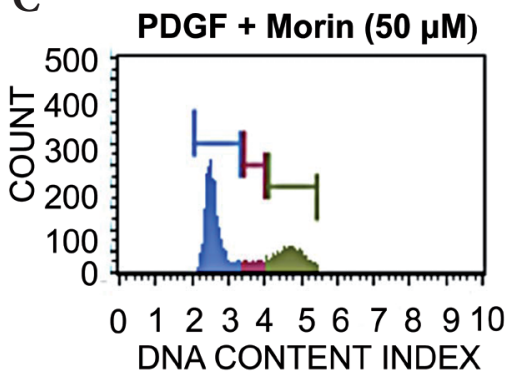

$\mathbf{F}$

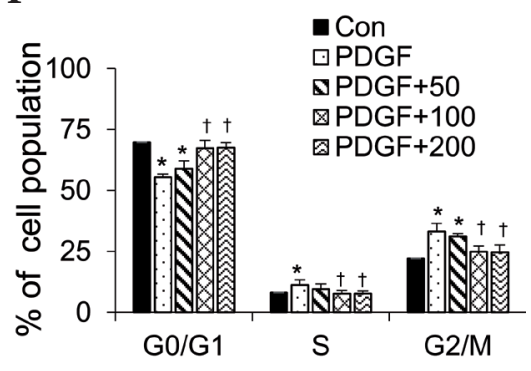

Figure 2. Cell-cycle distribution of PDGF-induced VSMCs treated with morin. Morin induced G1-phase cell-cycle arrest in VSMCs. VSMCs were preincubated with different concentrations of morin for $1 \mathrm{~h}$, followed by incubation with PDGF (20 ng/ml) for $24 \mathrm{~h}$. FACS histograms are presented for Control (Con, A), PDGF alone (B), $50 \mu \mathrm{M}$ morin with PDGF (C), $100 \mu \mathrm{M}$ morin with PDGF (D), $200 \mu \mathrm{M}$ morin with PDGF (E). Distribution of cell population is presented as percentages of cell population in each cell cycle phase $(\mathbf{F})$. Values are presented as means \pm SD of three independent experiments; ${ }^{*} p<0.05$ versus control, $\dagger p<0.05$ versus $\mathrm{PDGF}$ alone. 
A

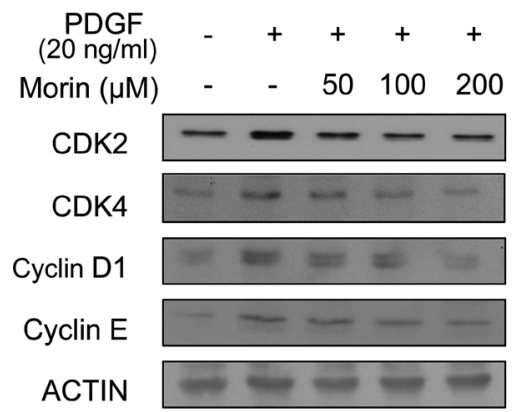

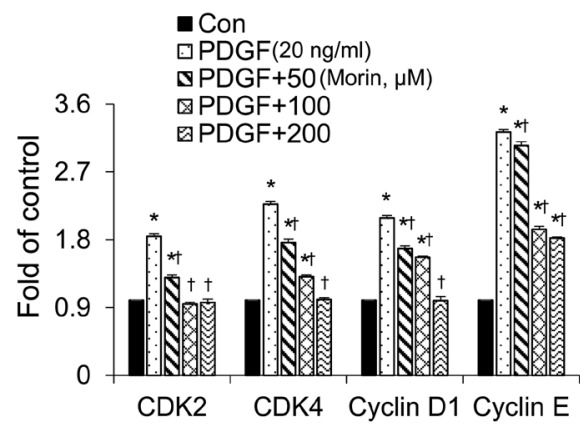

- Con

PDGF+100

B

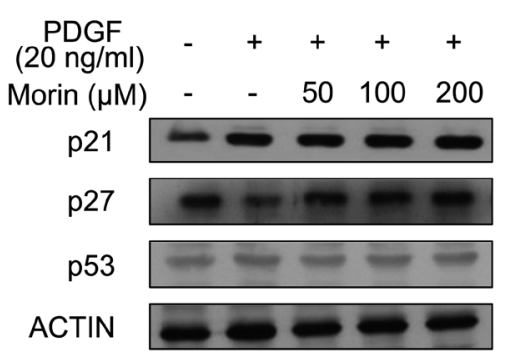

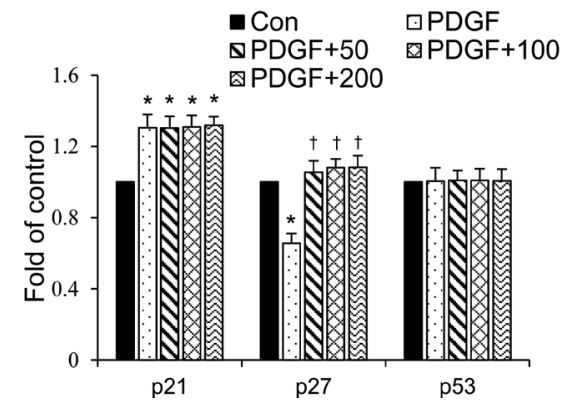

C PDGF (20ng/ml) - + + + Morin $(\mu \mathrm{M}) \quad 0 \quad 0 \quad 100$

IP: CDK2 / IB: p27 IP: CDK2 / IB: CDK2 - - -

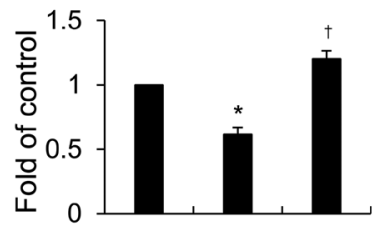

IP: CDK4 / IB: p27 $-\infty$ IP : CDK4 / IB: CDK4 $--$

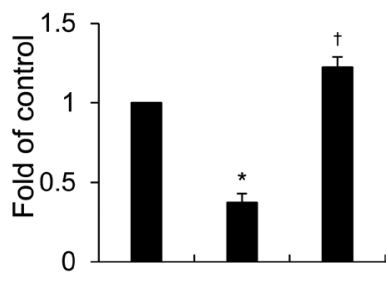

Figure 3. Effect of morin on cell cycle regulatory proteins in PDGF-induced VSMCs. Immunoblots were performed with antibodies specific for CDK2, CDK4, cyclin D1, and cyclin E (A) and p21WAF1, p27KIP1 and p53 (B). Actin was used as a loading control (Con). Equal amounts of cell lysates were subjected to immunoprecipitation using anti-CDK2 and anti-CDK4 antibodies, followed by immunoblotting with anti-p27KIP1 antibody $(\mathbf{C})$. All graphs represent the relative expression of the corresponding proteins on the blots. Values are presented as means \pm SD of three independent experiments; ${ }^{*} p<0.05$ versus control, $\dagger p<0.05$ versus $\mathrm{PDGF}$ alone.

Morin inhibits PDGF-induced proliferation of VSMCs via the AKT signaling pathway

MAPK and AKT signaling pathways are well known to play key roles in signal transduction from extracellular stimuli to the cytoplasm (Li et al. 2012). Thus, we investigated whether MAPKs (ERK, p-38, and JNK) and AKT signaling participate in the regulatory mechanism of morin-mediated growth inhibition of PDGF-stimulated VSMCs. Treatment of VSMCs with PDGF significantly induced phosphorylation of ERK, p-38, and JNK. However, pre-incubation with morin did not affect the PDGF-mediated phosphorylation of MAPKs. We then examined phosphorylation of AKT in response to PDGF, which was significantly increased more than 10-fold, compared to control levels. Interestingly, preincubation of the cells with morin significantly suppressed the PDGF-induced phosphorylation of AKT in a concentration-dependent manner (Figure 4A). In order to examine the association of AKT pathway with the cell cycle regulators, we utilized the AKT inhibitor, LY294002. VSMCs were treated with PDGF in the presence or absence of morin, followed by incubation with or without AKT inhibitor. As shown in Figure 4B, CDK2, CDK4, cyclin D1, and cyclin E levels were increased by PDGF (Figure 4B). These protein levels induced by PDGF were reversed by morin treatment. However, when LY294002 was added, these inhibitory effects of morin against the cell cycle regulators were reversed again. This result suggests that AKT signaling pathway is closely associated with the cell cycle regulators.

\section{Morin treatment reduces the migratory potential of PDGF-induced VSMCs}

Previous studies by other groups have suggested that migration of VSMCs to the intimal layer of the artery is a crucial step in the onset of atherosclerosis (Bendeck et al. 1994; Singh et al. 2002). Therefore, we examined whether morin affects the migratory activity of PDGF-induced VSMCs. To this end, we scratched the cell surfaces with a pipette tip followed by treatment as indicated. The distance of cellular migration after $24 \mathrm{~h}$ was compared to that of the control. As shown in Figure 5A, PDGF treatment promoted the 
migration of VSMCs. Pretreatment with morin, followed by PDGF treatment, strongly inhibited the migratory potential of VSMCs. In addition, treatment with morin alone did not affect the migration of VSMCs (Figure 5A). Taken together, these data indicate that morin suppresses the migration of VSMCs induced by PDGF.

Morin suppresses the Matrigel-degrading potential of PDGF- induced VSMCs

It has been reported that VSMCs generate MMPs in atherosclerotic lesions to penetrate the extracellular matrices of the vascular walls (Fabunmi et al. 1996). We examined whether morin inhibits the invasive potential of VSMCs using Matrigel-coated transwell chambers. As shown in Figure $5 \mathrm{~B}, \mathrm{PDGF}$ treatment significantly promoted the invasion of
VSMCs. However, preincubation with morin suppressed the Matrigel-degrading potential of VSMCs in response to PDGF. Treatment with morin alone had no effect on the invasion of VSMCs, compared with that of control (Figure 5B).

\section{Morin inhibits PDGF-stimulated MMP-9 expression} through the suppression of $N F-\kappa B, A P-1$, and Sp-1 binding activities

Previous studies have suggested that MMPs are crucial mediators in the proliferation and migration of VSMCs (Suh et al. 2006; Seo et al. 2015). Thus, we examined the gelatinase activities of MMP-2 and -9 in VSMCs using gelatin zymography. PDGF treatment exhibited enhanced gelatin-degrading activity of MMP-9 in VSMCs; however, MMP-2 was not effectively induced by the same treatment. Pre-incubation of the cells with morin at different concentrations $(50,100$,
A
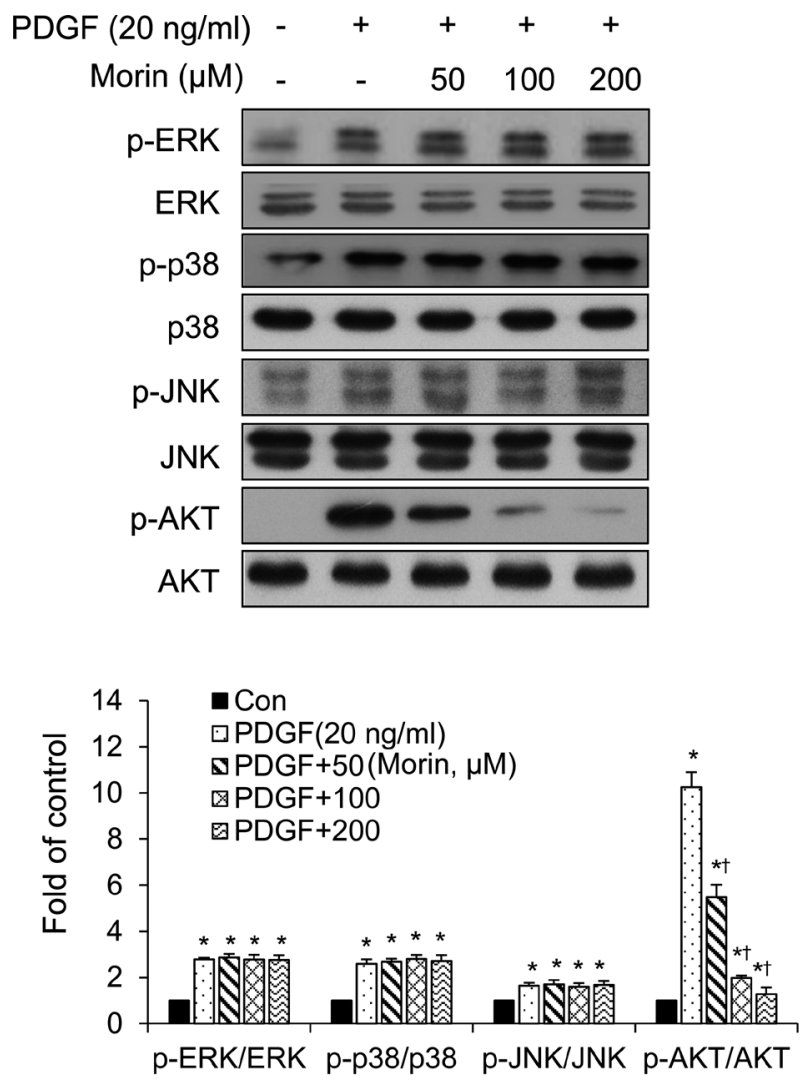

B
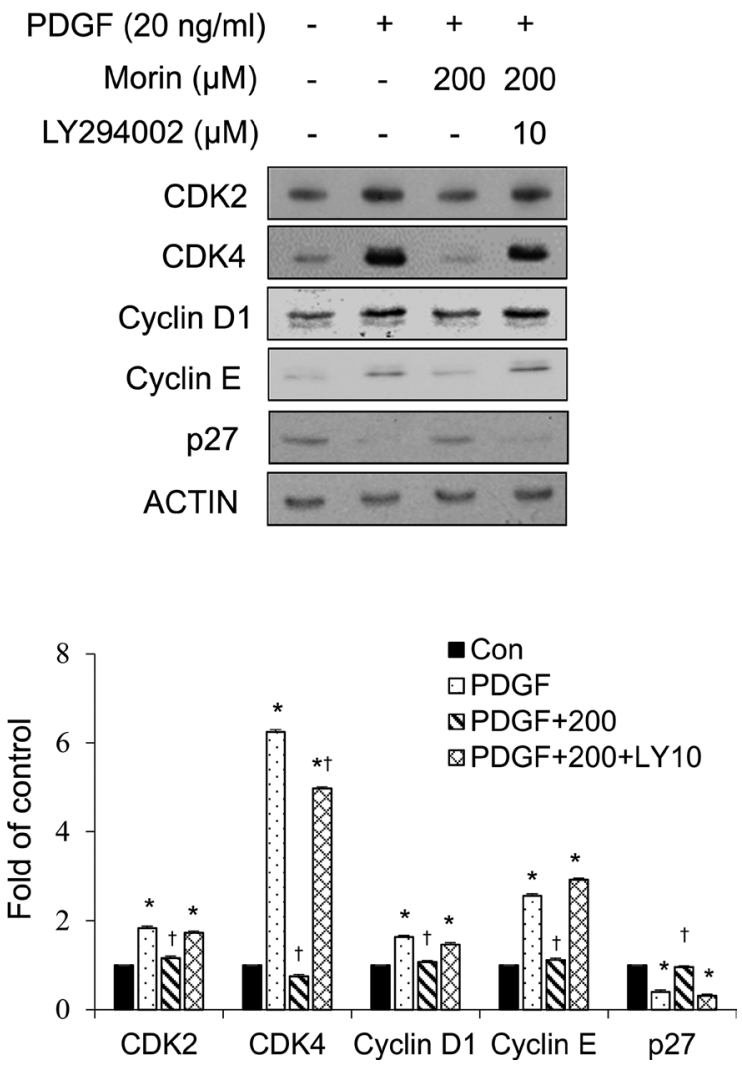

Figure 4. Effect of morin on MAPKs and AKT in PDGF-treated VSMCs. A. VSMCs were pretreated with morin at concentrations of 50, 100 , and $200 \mu \mathrm{M}$, followed by PDGF ( $20 \mathrm{ng} / \mathrm{ml})$. Cell lysates were prepared and subjected to immunoblots with specific antibodies against phospho-ERK1/2, ERK1/2, phospho-p38, p38, phospho-JNK, JNK, AKT, and phospho-AKT. The ratio of the phosphorylated form to the un-phosphorylated protein was evaluated and presented as a fold change compared to that of the control. B. Cells were pretreated with morin at 0 and $200 \mu \mathrm{M}$, followed by PDGF $(20 \mathrm{ng} / \mathrm{ml})$ in the presence or absence of LY294002. Western blots were performed against proteins indicated. Each value is presented as the mean $\pm \mathrm{SD}$ of three independent experiments; ${ }^{\star} p<0.05$ versus control, $\dagger p<$ 0.05 versus PDGF alone. 
A
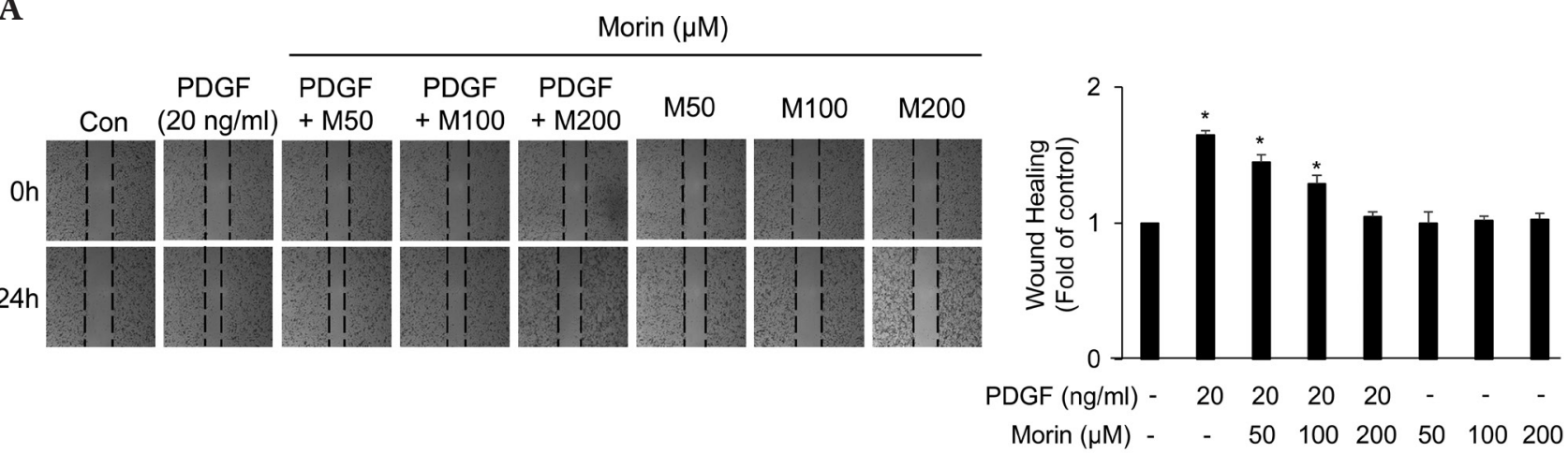

B

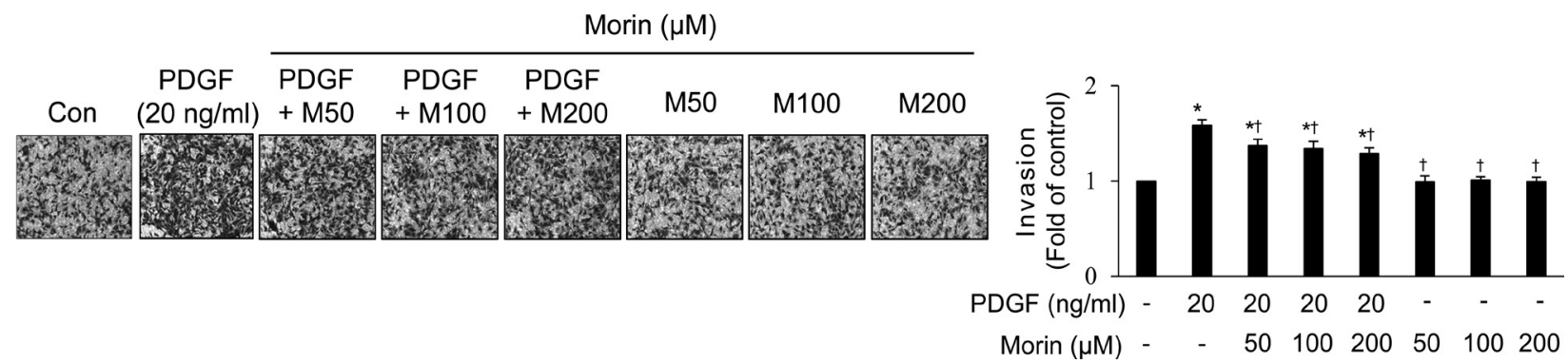

Figure 5. Inhibition of the migratory and invasive potential of PDGF-induced VSMCs by morin. Quiescent VSMCs were pretreated with 50,100, or $200 \mu \mathrm{M}$ of morin for $1 \mathrm{~h}$, and then cells were treated with or without PDGF $(20 \mathrm{ng} / \mathrm{mL})$ for $24 \mathrm{~h}$. A. Wound closure rate of VSMCs was monitored using phase contrast microscopy. The scratched area in the well is bounded by dashed lines. B. VSMCs were cultured in Matrigel-coated transwell plates. Invasive cells were quantified by blind counting under a microscope (40× magnification). The number of transmigrated cells was counted in eight randomly selected fields and the averages were calculated. The graph shows the fold change, relative to the control value. Values are presented as means \pm SD of three independent experiments; ${ }^{*} p<0.05$ versus control, $\uparrow p<0.05$ versus PDGF alone.

and $200 \mu \mathrm{M}$ ) inhibited the PDGF-induced gelatin-degrading activity of MMP-9, as evidenced by the reduced band with $200 \mu \mathrm{M}$ of morin treatment. In order to assure zymography results, we performed western immunoblot for MMP-9. As shown in Figure 6A, expression of MMP-9 was detected. To ensure the inhibitory activity of morin against MMP-9, we examined the mRNA expression in PDGF-activated VSMCs treated with or without morin. Cells treated with morin exhibited down-regulation of mRNA expression by morin treatment in a concentration dependent manner (Figure 6B). In order to understand the regulatory mechanism of the reduced MMP- 9 activity by morin in PDGF-induced VSMCs, we investigated the binding activities of the transcription factors, NF- $\mathrm{kB}, \mathrm{AP}-1$, and Sp-1, to their corresponding response element sequences in the MMP-9 promoter region, using EMSA. As shown in Figure 6C, the binding activities of NF- $\kappa \mathrm{B}, \mathrm{AP}-1$, and Sp-1 were increased in the nuclear extract from PDGF-treated VSMCs. However, these activities were markedly inhibited by preincubation with morin (Figure 6C). These results suggest that the inhibitory effect of morin against MMP-9 activity was attributed to the reduced binding of transcription factors, NF- $\kappa B, A P-1$, and Sp-1, and subsequent down-regulation of transcription.

\section{Discussion}

Atherosclerosis, a chronic inflammatory disease in the vascular walls, is characterized by the development of arterial lesions, containing lipids, immune cells, and cellular debris (Hansson 2005). Chronic stimulation from inflammatory cells dramatically reduces the stability of atherosclerotic plaques and promotes the proliferation and migration of VSMCs, which eventually leads to the narrowing of arterial vessels and thrombosis (Kofler et al. 2005).

Morin is a flavonol mainly found in plants of the Moraceae family. It has been widely utilized as an ingredient of herbal medicines due to its diverse biological activities (Iwase et al. 2001; Brown et al. 2003). Previous studies by others have demonstrated that morin exhibits strong anti-inflammatory 
and antioxidative activities in various cells and animal models by suppressing regulators of inflammation, including inducible nitric oxide synthase (iNOS), cyclooxygenase-2 (COX-2), and prostaglandin E2 (PGE2) (Kim et al. 2010; Chen et al. 2012, 2017; Wang et al. 2013). However, despite its positive pharmacological effects, research on the preventive effect of morin against atherosclerosis has been very limited. In this study, we investigated the mechanism of morin's activity that is associated with cell cycle regulatory proteins, signaling pathways, and transcription factor-mediated MMP-9 expression in VSMCs induced by PDGF.

Given that atherosclerosis is pathologically a chronic inflammatory disease where VSMCs, at least in part, play a role in the process of atherosclerosis, we first investigated whether morin inhibits the proliferation of VSMCs. VSMCs proliferate upon stimulation with inflammatory cytokines or growth factors, such as IGF, hepatocyte growth factor (HGF), and PDGF (Avena et al. 1999; Li et al. 2000; Taher et al. 2002). We utilized PDGF to stimulate the proliferation of VSMCs. In the results of the MTT and cell counting assay, pretreatment of the VSMCs with morin significantly hampered their PDGF-induced proliferation in a concentration-dependent manner. Notably, treatment with morin alone in the absence of PDGF did not exhibit any cytotoxicity.

VSMCs are normally quiescent, but stimuli from growth factors including PDGF may induce cell cycle progression and eventually abnormal growth after vascular injury (Doran et al. 2008). Thus, modulating activity of cell cycle regulators may be a good strategy for inhibiting PDGFmediated VSMC proliferation. Although morin displays anti-proliferative activity against both normal hepatocytes (MadanKumar et al. 2014) and cancerous cells (Shin et al. 2017; Zhang et al. 2018), little has been reported on the cell cycle distribution profile mediated by morin in VSMCs.
A

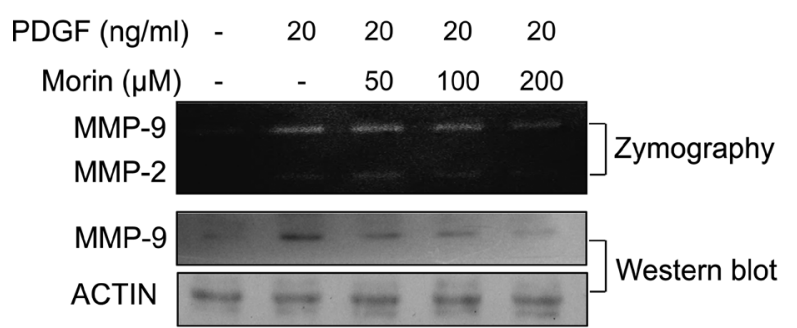

B

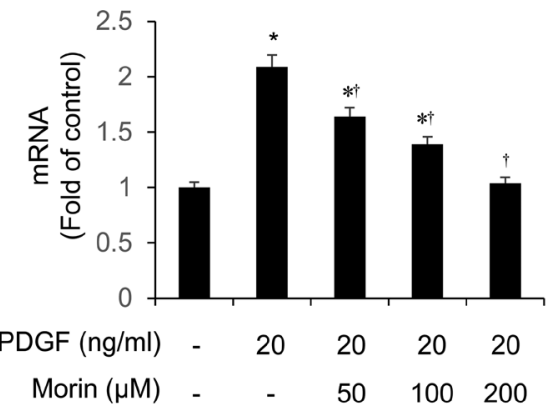

C

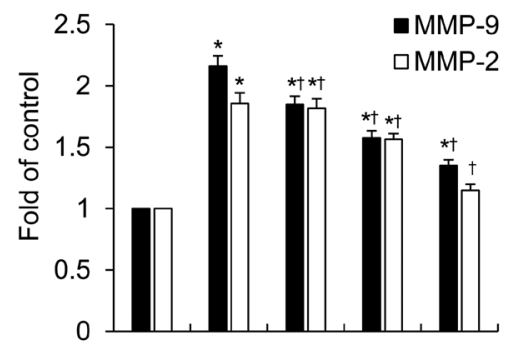

Figure 6. Morin suppresses MMP-9 expression through decreased binding activities of NF- $\kappa \mathrm{B}, \mathrm{AP}-1$, and Sp-1 motifs in PDGF-induced VSMCs. Quiescent VSMCs were preincubated with morin $(50,100$, or $200 \mu \mathrm{M})$ for $1 \mathrm{~h}$ followed by incubation with PDGF (20 ng/ $\mathrm{ml}$ ) for $24 \mathrm{~h}$. A. Culture supernatants were analyzed by zymography for the gelatinase enzymatic activities

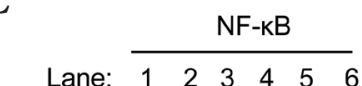

PDGF (ng/ml) Pos - 20202020 Morin $(\mu \mathrm{M})$ - - -100200 Competitor
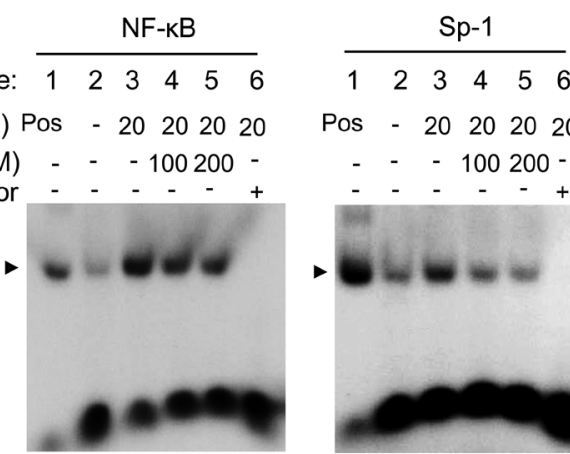

$\begin{array}{llllll}1 & 2 & 3 & 4 & 5 & 6\end{array}$

- $\quad-100200-$
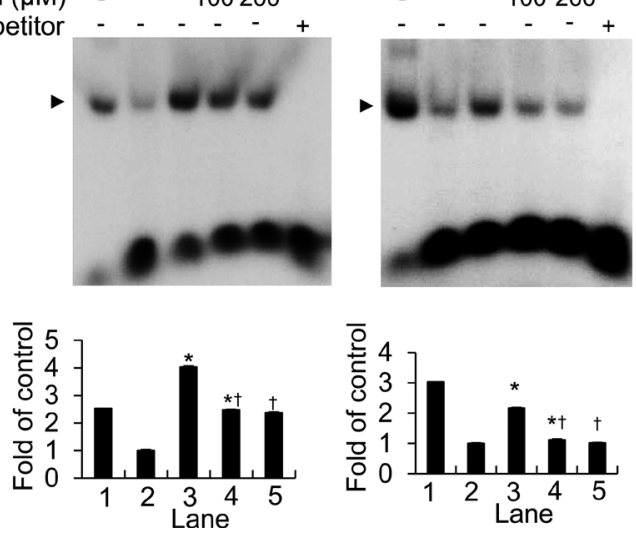
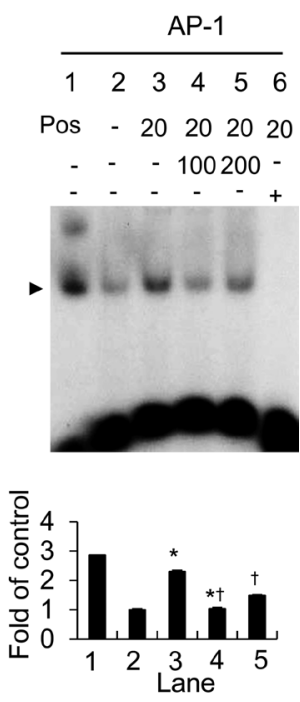
MMP-2 and MMP-9. Changes of MMP-9 protein levels by indicated treatments were also measured by Western immunoblots. Bar graph represents relative fold changes compared to the control. B. Relative expression of mRNAs was measured by RT-PCR and represented as fold changes compared to the control. C. The binding activities of Sp-1, AP-1 and NF- $\kappa$ B from the nuclear extracts were analyzed using EMSA with radiolabeled oligonucleotide probes. Activated HeLa nuclear extracts (Promega, HeLaScribe) was used as a positive control (pos). Bar graphs show relative fold changes compared to the positive control. Values are presented as means \pm SD of three independent experiments; ${ }^{*} p<0.05$ versus control, $\dagger p<$ 0.05 versus PDGF alone. 
Therefore, we investigated cell cycle phase distribution using flow cytometry with morin-treated VSMCs. In our data, morin induced growth arrest of VSMCs at G1-phase in a concentration-dependent manner. Since the G1 cell cycle checkpoint has been reported as a prominent target associated with many chemotherapeutic agents (Li et al. 2004; Lin et al. 1998), we examined the cell cycle regulatory proteins associated with it. Immunoblot analysis revealed that morin disturbs PDGF-mediated mitogenic signals, as indicated by reduced protein expression of cyclin D1, cyclin E, CDK2, and CDK4 in VSMCs pretreated with morin, followed by PDGF stimulation. These results suggest that the anti-proliferative effect of morin is caused by the G1-phase cell cycle arrest associated with down-regulation of cyclins and CDKs in PDGF-stimulated VSMCs.

The activity of cyclin/CDK complexes is tightly regulated by CDKIs, such as p21WAF1 and p27KIP1 (Xiong et al. 1993). CDKIs tightly bind to cyclin/CDK complexes and inhibit their activities (Xiong et al. 1993). A previous study by another group demonstrated that p27KIP1 expression was markedly decreased after vascular injury (Tanner et al. 1998). In addition, overexpression of p27KIP1 has been shown to inhibit intimal VSMCs, which reduces neointimal hyperplasia in the internal carotid artery (Chen et al. 1997). The present study showed a reduction in p27KIP1 expression in PDGF-treated VSMC. This effect was reversed after morin treatment, suggesting that morin-induced p27KIP1 is responsible for G1 arrest in PDGF-treated VSMCs. p21WAF1 was originally described as a cell cycle inhibitor (Xiong et al. 1993; Toyoshima and Hunter 1994). However, several studies have since demonstrated that p21WAF1 is involved also in VSMC proliferation (Tanner et al. 1998). In our current study, PDGF was shown to be an inducer of p21WAF1 expression, but p21WAF1 levels were not influenced by the pretreatment with morin. Furthermore, the expression level of 53 protein was unchanged upon PDGF treatment. These results suggest that the morin-induced G1-phase cell cycle arrest is caused by decreased expression of CDK/cyclin complexes and induction of p27KIP1 in PDGF-treated VSMCs.

It has been reported that protein regulators in early signaling cascades, such as MAPKs and AKT, are crucial mediators in the proliferation of VSMCs (Lee et al. 2007; Cui et al. 2014). Because many flavonoids inhibit the phosphorylation of MAPKs, such as ERK, JNK, and p38, we examined alterations in the phosphorylation of these proteins by morin. In our results, however, the PDGF-induced phosphorylation of MAPKs was unchanged by morin treatment, suggesting that different signaling pathways are utilized in the inhibitory mechanism. Thus, we examined phosphorylation of AKT in response to PDGF and morin treatments. Interestingly, phosphorylation of AKT was significantly increased by PDGF treatment. Pre-incubation with morin remarkably inhibited this PDGF-mediated phosphorylation of AKT. Jung and col- leagues reported that morin attenuates lipopolysaccharide (LPS)-induced inflammatory responses in neuronal cells both in vitro and in vivo by down-regulating MAPKs and AKT (Jung et al. 2017). Our results demonstrate that AKT signaling is involved in the inhibition of PDGF-mediated proliferation of VSMCs in response to morin.

Migration and invasion of VSMCs play important roles in the formation of atherosclerotic lesions (Galis et al. 2002a; Rudijanto 2007; Doran et al. 2008). Our data show that morin markedly suppresses the PDGF-mediated induction of migration and invasion of VSMCs. Treatment with morin alone did not affect the migratory and invasive pattern of VSMCs, supporting the protective activity of morin, without cytotoxicity to VSMCs. MMPs play crucial roles in both wound healing and vascular remodeling processes (Newby and Zaltsman 2000). Among MMPs, MMP-9 is inducible by stimulatory signals from vascular injury, but is not expressed in normal arteries (Brown et al. 1995). Therefore, our next experiments focused on the regulation of MMP-9 in VSMCs. Our zymography and Western immunoblot data showed that PDGF-mediated MMP-9 activity in VSMCs was suppressed by morin treatment in a concentration-dependent manner. These results suggest that the morin-mediated inhibition of MMP-9 activity contributes, at least in part, to suppression of the migration and invasion of hyper-proliferative VSMCs.

Previous studies showed that transcription factors, including NF- $\kappa \mathrm{B}, \mathrm{AP}-1$, and Sp-1, are associated with MMP-9 expression (Bond et al. 1998; Sato et al. 1993). We investigated whether these transcription factors participate in the morinmediated inhibition of MMP-9 activity. We performed EMSA using oligonucleotide probes of NF- $\kappa \mathrm{B}, \mathrm{AP}-1$, and $\mathrm{Sp}$-1 derived from the corresponding cis-elements in the MMP-9 promoter region. Consistent with the zymographic data, the EMSAs showed that morin treatment induced a significant decrease in the binding activities of Sp-1, AP1 , and NF- $\kappa \mathrm{B}$ in PDGF-treated VSMCs. Collectively, these data suggest that morin treatment inhibited the migration and invasion of VSMCs in response to PDGF via reduction of MMP-9 by the suppression of NF- $\kappa$ B, AP-1, and Sp-1 transcriptional activities.

In conclusion, our study showed that morin treatment significantly inhibited the proliferation, migration, and invasion of VSMCs stimulated by PDGF, without causing cytotoxicity. The inhibition of VSMC proliferation by morin was associated with G0/G1 phase cell arrest by downregulation of CDK2, CDK4, cyclin D1, and cyclin E and increased expression of p27KIP1. In addition, among early response signaling, AKT was identified as a key regulator in the morin-mediated inhibitory mechanism, but not MAPKs. Furthermore, morin effectively suppressed PDGF-induced activity of MMP-9 via down-regulation of Sp-1, AP-1 and NF- $\kappa \mathrm{B}$ binding activity, which resulted in the reduced migration and invasion of VSMCs. Therefore, these results may 
indicate therapeutic potential of morin for the prevention of cardiovascular disease associated with several pathological events, including proliferation, migration, and invasion of VSMCs. Further study is needed to examine the efficacy of morin using animal models.

Acknowledgments. This work was supported by the National Research Foundation of Korea (NRF) grant funded by the Korea government (MSIP) (No.2017R1A2B4009384). This research was also supported by Basic Science Research Program through the National Research Foundation of Korea (NRF) funded by the Ministry of Education, Science and Technology (No.2016R1C1B1016075).

Conflict of interest. The authors report no conflicts of interest in this work.

\section{References}

Avena R, Mitchell ME, Carmody B, Arora S, Neville RF, Sidaway AN (1999): Insulin-like growth factor-1 receptors mediate infragenicular vascular smooth muscle cell proliferation in response to glucose and insulin not by insulin receptors. Am. J. Surg. 178, 156-161 https://doi.org/10.1016/S0002-9610(99)00150-6

Azahri NS, Di Bartolo BA, Khachigian LM, Kavurma MM (2012): Sp1, acetylated histone-3 and p300 regulate TRAIL transcription: mechanisms of PDGF-BB-mediated VSMC proliferation and migration. J. Cell Biochem. 113, 2597-2606 https://doi.org/10.1002/jcb.24135

Bendeck MP, Zempo N, Clowes AW, Galardy RE, Reidy MA (1994): Smooth muscle cell migration and matrix metalloproteinase expression after arterial injury in the rat. Circ. Res. 75, 539-545 https://doi.org/10.1161/01.RES.75.3.539

Bond M, Fabunmi RP, Baker AH, Newby AC (1998): Synergistic upregulation of metalloproteinase- 9 by growth factors and inflammatory cytokines: an absolute requirement for transcription factor NF-kappa B. FEBS Lett 435, 29-34 https://doi.org/10.1016/S0014-5793(98)01034-5

Brown DL, Hibbs MS, Kearney M, Loushin C, Isner JM (1995): Identification of $92-\mathrm{kD}$ gelatinase in human coronary atherosclerotic lesions. Association of active enzyme synthesis with unstable angina. Circulation 91, 2125-2131

https://doi.org/10.1161/01.CIR.91.8.2125

Brown J, O'Prey J, Harrison PR (2003): Enhanced sensitivity of human oral tumours to the flavonol, morin, during cancer progression: involvement of the Akt and stress kinase pathways. Carcinogenesis 24, 171-177 https://doi.org/10.1093/carcin/24.2.171

Caird J, Napoli C, Taggart C, Farrell M, Bouchier-Hayes D (2006): Matrix metalloproteinases 2 and 9 in human atherosclerotic and non-atherosclerotic cerebral aneurysms. Eur. J. Neurol. 13, 1098-1105 https://doi.org/10.1111/j.1468-1331.2006.01469.x

Chase AJ, Newby AC (2003): Regulation of matrix metalloproteinase (matrixin) genes in blood vessels: a multi-step recruitment model for pathological remodelling. J. Vasc. Res. 40, 329-343

https://doi.org/10.1159/000072697

Chen D, Krasinski K, Sylvester A, Chen J, Nisen PD, Andres V (1997): Downregulation of cyclin-dependent kinase 2 activity and cyclin A promoter activity in vascular smooth muscle cells by $\mathrm{p} 27$ (KIP1), an inhibitor of neointima formation in the rat carotid artery. J. Clin. Invest. 99, 2334-2341

https://doi.org/10.1172/JCI119414

Chen WP, Wang YL, Tang JL, Hu PF, Bao JP, Wu LD (2012): Morin inhibits interleukin-1beta-induced nitric oxide and prostaglandin E2 production in human chondrocytes. Int. Immunopharmacol. 12, 447-452

https://doi.org/10.1016/j.intimp.2011.12.024

Chen Y, Li Y, Xu H, Li G, Ma Y, Pang YJ (2017): Morin Mitigates Oxidative Stress, Apoptosis and Inflammation in Cerebral Ischemic Rats. Afr. J. Tradit. Complement Altern. Med. 14, 348-355 https://doi.org/10.21010/ajtcam.v14i2.36

Chistiakov DA, Orekhov AN, Bobryshev YV (2015): Vascular smooth muscle cell in atherosclerosis. Acta Physiol. (Oxf) 214, 33-50

https://doi.org/10.1111/apha.12466

Cho A, Graves J, Reidy MA (2000): Mitogen-activated protein kinases mediate matrix metalloproteinase- 9 expression in vascular smooth muscle cells. Arterioscler. Thromb. Vasc. Biol. 20, 2527-2532

https://doi.org/10.1161/01.ATV.20.12.2527

Cho A, Reidy MA (2002): Matrix metalloproteinase-9 is necessary for the regulation of smooth muscle cell replication and migration after arterial injury. Circ. Res. 91, 845-851 https://doi.org/10.1161/01.RES.0000040420.17366.2E

Chung SS, Oliva B, Dwabe S, Vadgama JV (2016): Combination treatment with flavonoid morin and telomerase inhibitor MST312 reduces cancer stem cell traits by targeting STAT3 and telomerase. Int. J. Oncol. 49, 487-498 https://doi.org/10.3892/ijo.2016.3546

Cui Y, Sun YW, Lin HS, Su WM, Fang Y, Zhao Y, Wei XQ, Qin YH, Kohama K, Gao Y (2014): Platelet-derived growth factor-BB induces matrix metalloproteinase- 2 expression and rat vascular smooth muscle cell migration via ROCK and ERK/p38 MAPK pathways. Mol. Cell Biochem. 393, 255-263 https://doi.org/10.1007/s11010-014-2068-5

Doran AC, Meller N, McNamara CA (2008): Role of smooth muscle cells in the initiation and early progression of atherosclerosis. Arterioscler. Thromb. Vasc. Biol. 28, 812-819

https://doi.org/10.1161/ATVBAHA.107.159327

Fabunmi RP, Baker AH, Murray EJ, Booth RF, Newby AC (1996): Divergent regulation by growth factors and cytokines of 95 $\mathrm{kDa}$ and $72 \mathrm{kDa}$ gelatinases and tissue inhibitors or metalloproteinases-1, -2 , and -3 in rabbit aortic smooth muscle cells. Biochem. J. 315, 335-342 https://doi.org/10.1042/bj3150335

Galis ZS, Johnson C, Godin D, Magid R, Shipley JM, Senior RM, Ivan E (2002a): Targeted disruption of the matrix metalloproteinase- 9 gene impairs smooth muscle cell migration and geometrical arterial remodeling. Circ. Res. 91, 852-859 https://doi.org/10.1161/01.RES.0000041036.86977.14 
Galis ZS, Khatri JJ (2002b): Matrix metalloproteinases in vascular remodeling and atherogenesis: the good, the bad, and the ugly. Circ. Res. 90, 251-262

https://doi.org/10.1161/res.90.3.251

Guo H, Shi Y, Liu L, Sun A, Xu F, Chi J (2009): Rosuvastatin inhibits MMP-2 expression and limits the progression of atherosclerosis in LDLR-deficient mice. Arch. Med. Res. 40, 345-351 https://doi.org/10.1016/j.arcmed.2009.07.006

Hansson GK (2005): Inflammation, atherosclerosis, and coronary artery disease. N. Engl. J. Med. 352, 1685-1695 https://doi.org/10.1056/NEJMra043430

Heldin CH, Westermark B (1999): Mechanism of action and in vivo role of platelet-derived growth factor. Physiol. Rev. 79, $1283-1316$ https://doi.org/10.1152/physrev.1999.79.4.1283

Iwase Y, Takemura Y, Ju-ichi M, Mukainaka T, Ichiishi E, Ito C, Furukawa H, Yano M, Tokuda H, Nishino H (2001): Inhibitory effect of flavonoid derivatives on Epstein-Barr virus activation and two-stage carcinogenesis of skin tumors. Cancer Lett. 173, 105-109 https://doi.org/10.1016/S0304-3835(01)00615-2

Jin H, Lee WS, Eun SY, Jung JH, Park HS, Kim G, Choi YH, Ryu CH, Jung JM, Hong SC, Shin SC, Kim HJ (2014): Morin, a flavonoid from Moraceae, suppresses growth and invasion of the highly metastatic breast cancer cell line MDA-MB231 partly through suppression of the Akt pathway. Int. J. Oncol. 45, 1629-1637 https://doi.org/10.3892/ijo.2014.2535

Jung JS, Choi MJ, Lee YY, Moon BI, Park JS, Kim HS (2017): Suppression of lipopolysaccharide-induced neuroinflammation by morin via MAPK, PI3K/Akt, and PKA/HO-1 signaling pathway modulation. J. Agric. Food Chem. 65, 373-382 https://doi.org/10.1021/acs.jafc.6b05147

Kanno S, Tomizawa A, Hiura T, Osanai Y, Shouji A, Ujibe M, Ohtake T, Kimura K, Ishikawa M (2005): Inhibitory effects of naringenin on tumor growth in human cancer cell lines and sarcoma S-180-implanted mice. Biol. Pharm. Bull. 28, 527-530 https://doi.org/10.1248/bpb.28.527

Kim JM, Lee EK, Park G, Kim MK, Yokozawa T, Yu BP, Chung HY (2010): Morin modulates the oxidative stress-induced NFkappaB pathway through its anti-oxidant activity. Free Radic. Res. 44, 454-461 https://doi.org/10.3109/10715761003610737

Kofler S, Nickel T, Weis M (2005): Role of cytokines in cardiovascular diseases: a focus on endothelial responses to inflammation. Clin. Sci. (Lond) 108, 205-213 https://doi.org/10.1042/CS20040174

Lee CW, Lin CC, Lin WN, Liang KC, Luo SF, Wu CB, Wang SW, Yang CM (2007): TNF-alpha induces MMP-9 expression via activation of Src/EGFR, PDGFR/PI3K/Akt cascade and promotion of NF-kappaB/p300 binding in human tracheal smooth muscle cells. Am. J. Physiol. Lung Cell Mol. Physiol. 292, L799-812 https://doi.org/10.1152/ajplung.00311.2006

Lee MH, Yang HY (2001): Negative regulators of cyclin-dependent kinases and their roles in cancers. Cell. Mol. Life Sci. 58, 1907-1922

https://doi.org/10.1007/PL00000826
Li A, Blow JJ (2001): The origin of CDK regulation. Nat. Cell Biol. 3, E182-184 https://doi.org/10.1038/35087119

Li J, Huang SL, Guo ZG (2000): Platelet-derived growth factor stimulated vascular smooth muscle cell proliferation and its molecular mechanism. Acta Pharmacol. Sin. 21, 340-344

Li MH, Ito D, Sanada M, Odani T, Hatori M, Iwase M, Nagumo M (2004): Effect of 5-fluorouracil on G1 phase cell cycle regulation in oral cancer cell lines. Oral Oncol. 40, 63-70 https://doi.org/10.1016/S1368-8375(03)00136-2

Li W, Mei X, Tu YY (2012): Effects of tea polyphenols and their polymers on MAPK signaling pathways in cancer research. Mini Rev. Med. Chem. 12, 120-126 https://doi.org/10.2174/138955712798995011

Lin HL, Chang YF, Liu TY, Wu CW, Chi CW (1998): Submicromolar paclitaxel induces apoptosis in human gastric cancer cells at early G1 phase. Anticancer Res. 18, 3443-3449

MadanKumar P, NaveenKumar P, Manikandan S, Devaraj H, NiranjaliDevaraj S (2014): Morin ameliorates chemically induced liver fibrosis in vivo and inhibits stellate cell proliferation in vitro by suppressing Wnt/beta-catenin signaling. Toxicol. Appl. Pharmacol. 277, 210-220 https://doi.org/10.1016/j.taap.2014.03.008

Massague J (2004): G1 cell-cycle control and cancer. Nature 432, 298-306 https://doi.org/10.1038/nature03094

Moon SK, Cha BY, Kim CH (2004): ERK1/2 mediates TNF-alphainduced matrix metalloproteinase- 9 expression in human vascular smooth muscle cells via the regulation of NF-kappaB and AP-1: Involvement of the ras dependent pathway. J. Cell. Physiol. 198, 417-427 https://doi.org/10.1002/jcp.10435

Newby AC, Zaltsman AB (2000): Molecular mechanisms in intimal hyperplasia. J. Pathol. 190, 300-309

https://doi.org/10.1002/(SICI)1096-9896(200002)190:3<300::AID-PATH596>3.0.CO;2-I

Ross R (1993): The pathogenesis of atherosclerosis: a perspective for the 1990s. Nature 362, 801-809 https://doi.org/10.1038/362801a0

Rudijanto A (2007): The role of vascular smooth muscle cells on the pathogenesis of atherosclerosis. Acta Med. Indones. 39, 86-93

Sato H, Kita M, Seiki M (1993): v-Src activates the expression of 92-kDa type IV collagenase gene through the AP-1 site and the GT box homologous to retinoblastoma control elements. A mechanism regulating gene expression independent of that by inflammatory cytokines. J. Biol. Chem. 268, 23460-23468

Seo KW, Lee SJ, Ye BH, Kim YW, Bae SS, Kim CD (2015): Mechanical stretch enhances the expression and activity of osteopontin and MMP-2 via the Akt1/AP-1 pathways in VSMC. J. Mol. Cell. Cardiol. 85, 13-24 https://doi.org/10.1016/j.yjmcc.2015.05.006

Shin SS, Won SY, Noh DH, Hwang B, Kim WJ, Moon SK (2017): Morin inhibits proliferation, migration, and invasion of bladder cancer EJ cells via modulation of signaling pathways, cell cycle regulators, and transcription factor-mediated MMP-9 expression. Drug Dev. Res. 78, 81-90 https://doi.org/10.1002/ddr.21377 
Singh RB, Mengi SA, Xu YJ, Arneja AS, Dhalla NS (2002): Pathogenesis of atherosclerosis: A multifactorial process. Exp. Clin. Cardiol. 7, 40-53

Sivaramakrishnan V, Niranjali Devaraj S (2009): Morin regulates the expression of NF-kappaB-p65, COX-2 and matrix metalloproteinases in diethylnitrosamine induced rat hepatocellular carcinoma. Chem. Biol. Interact. 180, 353-359 https://doi.org/10.1016/j.cbi.2009.02.004

Suh SJ, Jin UH, Kim SH, Chang HW, Son JK, Lee SH, Son KH, Kim CH (2006): Ochnaflavone inhibits TNF-alpha-induced human VSMC proliferation via regulation of cell cycle, ERK1/2, and MMP-9. J. Cell. Biochem. 99, 1298-1307 https://doi.org/10.1002/jcb.20912

Taher TE, Derksen PW, de Boer OJ, Spaargaren M, Teeling P, van der Wal AC, Pals ST (2002): Hepatocyte growth factor triggers signaling cascades mediating vascular smooth muscle cell migration. Biochem. Biophys. Res. Commun. 298, 80-86 https://doi.org/10.1016/S0006-291X(02)02397-5

Tanner FC, Yang ZY, Duckers E, Gordon D, Nabel GJ, Nabel EG (1998): Expression of cyclin-dependent kinase inhibitors in vascular disease. Circ. Res. 82, 396-403 https://doi.org/10.1161/01.RES.82.3.396

Toyoshima H, Hunter T (1994): p27, a novel inhibitor of G1 cyclin-Cdk protein kinase activity, is related to p21. Cell 78, $67-74$ https://doi.org/10.1016/0092-8674(94)90573-8

Turunen MP, Hiltunen MO, Yla-Herttuala S (1999): Gene therapy for angiogenesis, restenosis and related diseases. Exp. Gerontol. 34, 567-574 https://doi.org/10.1016/S0531-5565(99)00028-5
Wagsater D, Zhu C, Bjorkegren J, Skogsberg J, Eriksson P (2011): MMP-2 and MMP-9 are prominent matrix metalloproteinases during atherosclerosis development in the $\operatorname{Ldlr}(-/-)$ Apob(100/100) mouse. Int. J. Mol. Med. 28, 247-253

Wang X, Zhang DM, Gu TT, Ding XQ, Fan CY, Zhu Q, Shi YW, Hong Y, Kong LD (2013): Morin reduces hepatic inflammationassociated lipid accumulation in high fructose-fed rats via inhibiting sphingosine kinase 1/sphingosine 1-phosphate signaling pathway. Biochem. Pharmacol. 86, 1791-1804 https://doi.org/10.1016/j.bcp.2013.10.005

Xiong Y, Hannon GJ, Zhang H, Casso D, Kobayashi R, Beach D (1993): p21 is a universal inhibitor of cyclin kinases. Nature 366, 701-704

https://doi.org/10.1038/366701a0

Zetterberg A, Larsson O, Wiman KG (1995): What is the restriction point? Curr. Opin. Cell Biol. 7, 835-842 https://doi.org/10.1016/0955-0674(95)80067-0

Zhang Q, Zhang F, Thakur K, Wang J, Wang H, Hu F, Zhang JG, Wei ZJ (2018): Molecular mechanism of anti-cancerous potential of Morin extracted from mulberry in Hela cells. Food Chem. Toxicol. 112, 466-475 https://doi.org/10.1016/j.fct.2017.07.002

Zhuang J, Peng W, Li H, Lu Y, Wang K, Fan F, Li S, Xu Y (2013): Inhibitory effects of vinpocetine on the progression of atherosclerosis are mediated by Akt/NF-kappaB dependent mechanisms in apoE-/- mice. PLoS One 8, e82509 https://doi.org/10.1371/journal.pone.0082509

Received: March 2, 2018

Final version accepted: August 7, 2018 